\title{
Some Legal Uncertainties in Electronic Corporate Meetings
}

\author{
Hasani Mohd Ali, Zinatul A. Zainol, Jady@Zaidi Hassim, and Nor Hayati Abdul Samat
}

\begin{abstract}
Electronic meetings may offer a low cost and borderless medium of communication. Hence, shareholders' rights to participate may be enhanced. Legislatures in various jurisdictions have given electronic meetings a statutory recognition. This paper analyses the effectiveness of electronic corporate meetings from a legal perspective as provided by the legislation especially in Malaysia. Some experiences from other jurisdictions like US and Australia may be drawn for this purpose.
\end{abstract}

Index Terms-Virtual/electronic meetings, opportunity to participate, shareholders' rights, corporate governance.

\section{INTRODUCTION}

Meetings are an important form of decision making conducted by organizations like corporations. The most common type of corporate meetings can be divided into board meetings for the top management, and general meetings involving shareholders (members). The concerns over shareholders' right to information and participation have given rise to the inclusion of effective shareholders' meetings as part of the best practices in corporate governance. However, low shareholders' attendance is a typical scenario in most general meetings, i.e. the main issue against corporate governance activism. The advent of electronic meetings is a means to increase their participations. Electronic meetings may offer a low cost and borderless medium of communication; hence it could offer a solution to resolve shareholders passivism. Legislatures in various jurisdictions have given electronic meetings a statutory recognition. This paper will analyse the effectiveness of electronic corporate meetings from a legal perspective as provided by the legislation especially in Malaysia, since an amendment to the law was made in 2007. Some experiences from other jurisdictions like US and Australia may be drawn for this purpose.

Manuscript received September 3, 2012; revised November 17, 2012 This work was supported in part by Universiti Kebangsaan Malaysia under Grant UKM-UU-05-FRGS0083-2009

Hasani Mohd Ali and Jady@Zaidi Hassim are with the Faculty of Law, Universiti Kebangsaan Malaysia, 43600 UKM Bangi, Malaysia (e-mail: wsa@ukm.my, jady@ukm.my).

Zinatul A. Zainol is with the Faculty of Law, Universiti Kebangsaan Malaysia, 43600 UKM Bangi, Malaysia. She is the head of Biodiversity and Biotechnology Governance Research Group at UKM (e-mail: shiqin@ukm.my).

Nor Hayati Abdul Samat is with the College of Law, Government and International Studies, Universiti Utara Malaysia, 06010 Sintok, Kedah, Malaysia.

\section{MeEtingS AND Shareholders' RightS}

Meeting is at the heart of company's decision-making from which a company is managed. Company's meeting can either be in the form of directors' or shareholders' meetings. In terms of role and significance, they are equally important. However in practice, directors' meeting seems superior because a wider discretionary power is normally vested to the management. Nevertheless, some of the important issues are still left for shareholders to decide such as to alter the memorandum and articles of association. In fact, the position of each director may be determined by the shareholders e.g. their appointment, removal and reappointment. The shareholders' meeting is important as it provides a forum for discussion about the conduct of company's business [1]. It is a place also where shareholders exercise their fundamental right i.e. voting right. These are among the reasons on why a set of comprehensive laws on this area is needed.

The law regulating shareholders' meetings is important but relatively remains as a neglected aspect of corporate governance [2]. It has been argued that the complex problem of corporate governance requires, amongst others, the revival of shareholders' involvement in corporate decision-making. Corporate governance is well served when the shareholders show involvement in gathering information preceding, during and following the meeting. This leads irreversibly to well-informed resolutions. In other way, it also establishes a 'check and balance' system against director's managerial power [3]

In [4], rational apathy, asymmetrical information and unfortunate planning of annual general meeting may obstruct any increase in participation and involvement of shareholders. Kobler [1] noted that changes in corporate society structure through time, call for revolution in handling company's general meeting. Corporate ownership becomes widely dispersed with shareholders spread across greater geographical area. It becomes more and more inconvenient for shareholders to attend the meeting.

\section{LEGAL EVOLUTION ON THE CONCEPT OF MEETING}

The traditional view of what constitutes a meeting has evolved over time with the advancement of technology. Physical presence is no longer an essential element to prove that there is a valid meeting. This is proven by the change of court's attitude in deciding what amount to a valid meeting. The case of Byng $v$ London Life Assurance Limited [1990] 1 Ch 170 marked the changes in the concept of 'meeting'. In this case, a general meeting of London Life Assurance was held in few separate rooms connected by electronic 
audio-visual aid. The meeting was held as a valid meeting. The word 'meeting' now has been extended to meeting of mind (Bell v Burton (1993) 12 ACSR 325). In Wagner v International Health Promotions (1994)15 ACSR 419, a board meeting was held through telephone. In delivering his judgment, Santow J addressed the true meaning of 'the directors meeting together' as stated in the articles:

"I agree that the words "meet together" connote a meeting of mind made possible by modern technology and not of bodies" (at page $421-422$ )

Legislatures in several jurisdictions decided to adopt a contemporary approach and follow the trends of allowing technology to be used in a shareholders' meeting.

\section{EleCtronic MeETINGS IN VARIOUS JURISDICTIONS}

The initiative of e-navigation will reduce navigational errors such as shipping accidents and ship-sourced marine pollution in the Straits of Malacca and Singapore. It offers a lot of convenience to Malaysia in monitoring the vessel passing by the Straits. E-navigation should not be viewed as replacing traditional aids of navigation. Instead, e-navigation should come with traditional aids to navigation as electronic positioning signals are not failure-free. Traditional aids to navigation are still important and its combination with e-navigation may be the best approach.

\section{A. Delaware, USA}

One of the most known jurisdictions, which clearly allows shareholders' meeting to be entirely virtual, is Delaware, USA. In 1996, the Delaware-based Corporation, Bell \& Howell started to cast its Annual General Meeting online. At the time, Delaware statute in respect of shareholders meeting provided that:

"Meeting may be held at such place, either within or without the State, as may be designated by or in the manner provided in the bylaws or, if not so designated, at the registered office of the corporation in this State".

In the above meeting, there were 950 shareholders who followed the proceedings of the AGM online, but it was reported that they were not considered to be legally present, and therefore did not attend the meeting for quorum or voting purposes [5]. The above provision was then amended in the year 2000. The new provision of Title 8 section 211(a) (1) reads as follows:

"Meetings of stockholders may be held at such place, either within or without this State as may be designated by or in the manner provided in the certificate of incorporation or bylaws, or if not so designated, as determined by the board of directors. If, pursuant to this paragraph or the certificate of incorporation or the bylaws of the corporation, the board of directors is authorized to determine the place of a meeting of stockholders, the board of directors may, in its sole discretion, determine that the meeting shall not be held at any place, but may instead be held solely by means of remote communication as authorized by paragraph (a)(2) of this section"

This new provision permits all companies incorporated in Delaware to hold their general meeting not merely by an ordinary video-conference but entirely virtual. This makes
Delaware a jurisdiction that clearly sets aside the requirement of physical presence in a meeting. This provision is accompanied by additional requirements to be fulfilled. This is to ensure that the integrity of online shareholders meeting will be protected. First, the right to vote in virtual meeting is restricted only to shareholders and proxies. Second, the company must take reasonable steps to ensure that shareholders / proxies have reasonable opportunity to participate and vote. Third, the company shall maintain records of votes and actions at the meeting taking place through remote communication. In April 2001, a Chicago-based technology consultant, Inforte Corp., which was incorporated in Delaware, held its annual meeting over the Internet. It was done with 'No Complains' feedback [6].

Even though the state of Delaware allows meeting to be held entirely virtual, there was little evidence to show that it has been fully utilised by all companies in Delaware. Boros [7] stated that the unpopularity of the virtual shareholders' meeting in Delaware is caused by the fact that the General Corporation Law does not set concrete procedural requirements for a virtual shareholder meeting. There is no assurance that all questions will be answered by the directors and it lacks of supervision [4]

\section{B. Australia}

In Australia, the changes to company meetings involve the following aspects: modification of the rules on the holding of meetings; use of electronic technology to hold meetings; provision of notices of meetings; notice of meetings of listed company and a reasonable opportunity for members to ask questions or comment on the company's management. According to section 249S of the Australian Corporations Act provides that:-

"A company may hold a meeting of the member at two or more venues using any technology that givethe members as a whole a reasonable opportunity to participate."

Though the above provision empowers companies to hold their general meeting electronically, there is still no express provision allowing a meeting to be held in no place (entirely virtual). However, Professor Boros [7] holds that there is still possible to argue that section 249 S could actually extend to virtual meeting as well.

In Malaysia, the amended section 145A has similar wordings with those in section 249S of the Australian Corporations Act. Therefore, the same issues arise here as to whether virtual shareholders meeting is possible for Malaysian company. Abdul Samat [8] pointed out that the word "venues" could be literally interpreted as physical locations. Nonetheless, it may be argued that if the provision is interpreted according to a purposive approach, there is no reason to exclude the applicability of a virtual meeting.

\section{Malaysia}

In 2007, an amendment was made by the Malaysian Parliament to the Companies Act 1965, known as the Companies (Amendment) Act 2007 (The Act). There was an amendment made with respect to shareholders' electronic meeting. The provision concerned is section 145A that reads as follows: 
"A company shall hold all meetings of its members within Malaysia and may hold a meeting of its members within Malaysia at more than one venue using any technology that allows all members a reasonable opportunity to participate"

Under this new provision, a general meeting of a company is no longer confined to be held in a State where the registered office is situated but can be held anywhere within Malaysia. The most vital change is laid down in the second part of this provision. Malaysian companies may now hold their general meetings in more than one location with the aid of any technology.

Unfortunately, this development raises some questions left without any definite answers. It is uncertain as to what kind of technology a company may apply under this provision. The phrase "... at more than one venue..." suggests that there must be a physical location to hold a meeting and the location must be within Malaysia. One may argues that a virtual meeting has no physical venue to take place. This leaves us with a question on whether virtual meeting is possible under this provision. In comparison, in United States, the Delaware General Corporation Law specifically provides that a "shareholder's meeting shall not be held at any place but may instead be held solely by means of remote communications". The interpretation of the application of this section is wide open since section $145 \mathrm{~A}$ is the only provision on electronic meeting under the Malaysian Companies Act 1965. There is no further explanation or supporting provisions to complement it.

\section{ANALYSIS ON SPECIFIC ISSUES AFFECTING RIGHTS OF SHAREHOLDERS}

\section{A. Notice of Meeting}

Notice of meeting is notification of date, time and place to hold a meeting [9]. It shall list down all the businesses that will be transacted on the day of the meeting [10]. A notice is an expression of the sender's intention to call for a meeting. In respect of shareholders' meetings, it can either be from the company, (by order of the board) or from the company's members (special resolution or notice of requisition). Notice of meeting is served upon the shareholders pursuant to the procedures prescribed in the articles of each individual company [11]. Notice of meeting must be served on the shareholders, 14 or 21 days before the day fixed for a meeting An action can be taken to invalidate a meeting if it was called by an insufficient notice. Therefore, the length of notice to be served must be carefully calculated. The length of notice depends on types of resolution to be passed in such a meeting Method of calculation is based on number of clear days, (In re Hector Whaling Ltd. [1936] 1 Ch. 208) that are the day, such a notice is served or deems to be served and the day of the meeting is excluded in the calculation of 14 or 21 days.

Generally, mode of serving the notice depends on the articles of each company. Therefore if a company wishes to serve notice by means of electronic communication, it must be stated in the articles. However, in some jurisdictions, the application of electronic means in serving notice of meeting is enacted in the Statute. For instance, section 249J (3) of the Australian Corporations Act which provides serving is possible by fax or other electronic means.

In Malaysia, the issue of electronic notice of meeting is not specifically addressed by the 2007's amendment. The Statute which deals with electronic business communication is the Malaysian Electronic Commerce Act 2006. Unfortunately, this Statute is more suitable for commercial transactions [8] and even within its realm, the Statute has many flaws [12]. In the absence of any statutory provision concerning electronic notice of meeting, there is a concern that shareholders might refuse to co-operate in providing their electronic addresses [13]. This is because there is no assurance that privacy of information will always be maintained. By having a statutory provision, it may provide clarity in the law and it will facilitate the reduction of costs incurred in circulating such a notice to all the shareholders. In Hong Kong, on the other hand, the proposal is that serving notice on website should not be recommended. The choice is either to adopt electronic notice or not, and this is to be determined by the shareholders, example by incorporating it in the articles of the company [14].

\section{B. Reasonable Opportunity to Participate}

In maintaining proper order and preserving shareholders' rights throughout the meeting, a benchmark was placed that is the use of technology will always give shareholders opportunity to participate in the meeting. According to Professor Boros [15], shareholders' ability to vote is an essential element in determining whether remote participants have a reasonable opportunity to participate in the meeting. It can either be by direct electronic voting or proxy voting. Direct electronic voting is where shareholders are able to vote from remote computer terminals and votes are received directly by the company without being transferred by an appointed proxy [16]

In the meantime, an electronic proxy voting is where a shareholder votes through his proxy. Section 250A of the Australian Corporations Act provides that members are entitled to appoint proxy by signing an appointment form or by authenticating an appointment in a manner prescribed by the Corporations Regulations 2001 that permits electronic authentication. Regulation $2 \mathrm{G} 2.01(2)$ provides that if an electronic appointment is to be made by email or Internet-based voting, the member must be identified by personal details such as name and address. It further states that the member's approval of the information communicated must be communicated by a form of security protection such as shareholder's registration number.

There are a few advantages in using electronic voting. Electronic voting is much easier for individual investors; it offers a speed exchange of communication and it permits full scale of proxy solicitation to be accomplished. Electronic voting proves to be cost effective [16]. At the same time, electronic voting also has some drawbacks. Professor Dr. Aishah Bidin [14] pointed out that electronic transmission is not 100 percent reliable. Shareholders may encounter with busy telephone signals, slow web responses or server failure at either end of the communication chain.

The Australian Explanatory Memorandum to the Company Law Review Bill 1997 states that 'a reasonable opportunity to participate' does not require that each 
individual member has an opportunity to participate. For most companies, a reasonable opportunity to participate would mean that each member is able to communicate with the chairman and be heard by other members attending the meeting, including those at the other venues. However, whether there is such a 'reasonable opportunity' will depend upon the circumstances of the meeting [7]

Both aspects of participations (voting and deliberation in a meeting) were also being addressed by the Delaware's General Corporation Law. An "opportunity to participate" shall include an opportunity to hear and read the proceedings of the meeting in real-time. All votes and actions taken by shareholders through remote communications must be recorded (section 211 (a)(2)). As to Malaysia, the Companies Act 1965 is silent on the issue.

The position relating to the shareholders' right to participate in an electronic meeting in Delaware, Australia and Malaysia may be reflected in the following table:

TABLE I: SHAREHOLDERS’ RighTS IN ELECTRONIC MEETING.

\begin{tabular}{|c|c|c|c|}
\hline \multirow{2}{*}{ Provisions on- } & \multicolumn{3}{|c|}{ Jurisdictions } \\
\hline & Delaware & Australia & Malaysia \\
\hline $\begin{array}{l}\text { Allowing } \\
\text { electronic } \\
\text { meeting }\end{array}$ & $\begin{array}{c}\text { S } 211 \text { General } \\
\text { Corporation } \\
\text { Law }^{\mathrm{a}}\end{array}$ & $\begin{array}{c}\text { S 249S } \\
\text { Corporations } \\
\text { Act }^{\mathrm{b}}\end{array}$ & $\begin{array}{c}\mathrm{S} \mathrm{145A} \\
\text { Companies Act } \\
\mathrm{b}\end{array}$ \\
\hline $\begin{array}{l}\text { Reasonable } \\
\text { opportunity to } \\
\text { participate }\end{array}$ & $\begin{array}{l}\text { S211 General } \\
\text { Corporation } \\
\text { Act }^{\mathrm{c}}\end{array}$ & $\begin{array}{c}\text { Corporation } \\
\text { Regulation }^{2} \\
2001^{\mathrm{d}}\end{array}$ & $\begin{array}{c}\text { Not clearly } \\
\text { explained; } \\
\text { indirectly from } \\
\text { Electronic } \\
\text { Commerce Act } \\
2006\end{array}$ \\
\hline
\end{tabular}

- With clear provision of a meeting be held without any physical venue;

- Unclear as to the need of venue for a virtual meeting;

- Including right to hear and read the proceedings in real time;

- Relating to electronic authentication for direct or proxy voting.

\section{CONCLUSION}

Based on the above, the laws that allow virtual corporate meetings generally still suffer from many ambiguities especially relating to the extent scope of opportunity for the shareholders (members) to participate. The scope is interpreted differently from one jurisdiction to another. The range of rights that constitute an opportunity to participate in a meeting may include the right to communicate with and be heard by the chairman, right to hear and read the proceedings in real time, or right to vote directly or through a proxy. Similarly, unclear definitions are given for what constitute a valid notice of meeting, and how the law should provide for the adequacy of such a notice in terms of the acceptability of a particular electronic mode of service. The technology may be able to fulfill some or all the spectrum of rights expected by the members, but different versions of technology may cater different types of needs and rights at varying degrees. Besides, technology still suffers from the elements of unreliability e.g. relating to authentication and Internet coverage. It is potentially expensive, which may deprive most of the members of the companies who cannot afford to use it.

The law on corporate meeting is relatively still in its infancy to keep abreast with the technology. The technology itself is still finding its ways to innovate more sophisticated features in meeting most of the shareholders' rights and expectations. Technology therefore should be reliable and offered at the most reasonable price for a more consistent application among the users, who for this purpose, the corporations and their members.

\section{ACKNOWLEDGMENT}

The authors thank the Ministry of Higher Education for supporting this research under Fundamental Research Grant Scheme (FRGS) UKM-UU-05-FRGS0083-2009

\section{REFERENCES}

[1] G. P. Kobler, "Shareholder voting over the internet: A proposal for increasing shareholder participation in corporate governance," Ala. L. Rev. Winter, vol. 49, pp. 673-695, 1998.

[2] M. R. Salim and Y. S. Ong. The law of shareholders' meetings in Malaysia. International Company and Commercial Law Review. 2009. [Online]. Available: http://ssrn.com/abstract=1462686

[3] W. M. Pemmelaar, "Towards virtual a general meeting: 'I accept' or 'I declined'," 4 Utrecht Law Rev., vol. 4, pp. 163-169, 2008.

[4] A. V. D. Krans, "The virtual shareholders meeting: How to make it work," Journal of International Commercial Law and Technology, vol. 2, no. 1, pp. 32-38, 2007.

[5] M. D. Goldman and E. M. Filliben. Corporate governance: Current trends and likely developments for the twenty-first century. Delaware Journal for Corporate Law. [Online]. Available: http://papers.ssrn.com/sol3/papers.cfm?abstract_id=261757

[6] J. Graham, "Annual meeting need no walls can be held via the internet inforte got no complaints when it had shareholders meet in virtual gathering," Investor's Business Daily, November 7, 2001

[7] E. Boros. Virtual shareholder meetings. Duke L. \& Tech. Rev. 2004. [Online]. Available: http://www.law.duke.edu/journals/dltr/articles/pdf/2004DLTR0008

[8] N. H. A. Samat, "Penggunaan teknologi di dalam pemanggilan dan penganjuran mesyuarat syarikat," Sintok, Universiti Utara Malaysia. 2009.

[9] K. Dewan. Edisi 3. Kuala Lumpur, Dewan Bahasa dan Pustaka, 1994.

[10] K. S. Meng, "Directors' and shareholders' guide on annual general meeting," Kuala Lumpur: Malayan Law Journal. 2000.

[11] T. C. Han, Walter Woon on Company Law.3rd. Ed., Singapore, Sweet and Maxwell, 2005.

[12] A. B. Munir, "Electronic commerce bill 2006 an oversight or wanting a different," Malayan Law Journal, vol. 4, pp. i-xiii, 2006.

[13] A. Bidin, N. I. Yaakub, Z. A. Zainol, H. M. Ali, and S. Suhor, "Regulating online corporation: Issues and challenges for the corporate sector" Proceedings of 3rd. Conference on Law and Technology. Bangi, Universiti Kebangsaan Malaysia, pp. 11-12 November 2008

[14] A. Bidin, "Shareholders' Meetings in Cyberspace," Undang-Undang Dan Era Teknologi. Bangi, Universiti Kebangsaan Malaysia, 2008

[15] E. Boros. The online corporation: Electronic corporate Communication. [Online]. Available: http://cclsr.law.unimelb.edu.au/research-papers/online

[16] R. Alcock, A. Daly, and C. Conde. Electronic Proxy Voting in Australia. [Online]. Available: http://www.aar.com.au/pubs/cg/VotingPap 